\title{
UPAYA HUKUM TERHADAP PELANGGARAN HAK-HAK KONSTITUSIONAL WARGA NEGARA MELALUI PENGADUAN KONSTITUSIONAL (CONSTITUTIONAL COMPLAINT)
}

\author{
Galuh Candra Purnamasari \\ Fakultas Hukum, Universitas Katolik Parahyangan \\ email: galuhcandrap@unpar.ac.id \\ disampaikan 27/8/17 - di-review 12/11/17 - diterima 13/12/17 \\ DOI: $10.25123 /$ vej.2668
}

\begin{abstract}
The main argument of this paper is that there is an urgent need in Indonesia to expand the Constitutional Court's authority. The Constitutional Court should in the future be empowered to examine and decide constitutional complaints: a legal avenue for citizens to defend their constitutional rights in case of violations. The author shall discuss to what extent this legal institution can successfully be transplanted into the Indonesian legal and state system and what socio-political barriers can be expected to arise. A comparative law method shall be utilized.
\end{abstract}

Keywords:

constitutional rights; constitutional complaints; Constitutional Court.

\begin{abstract}
Abstrak
Argumentasi utama tulisan ini adalah perlu dan pentingnya memperluas kewenangan Mahkamah Konstitusi untuk memeriksa dan memutus constitutional complaint. Upaya hukum ini sejatinya disediakan bagi warga Negara untuk membela diri bilamana hak-hak konstitusional mereka sebagai warga dilanggar. Akan ditelaah di sini sejauh mana upaya hukum tersebut akan sejalan dengan sistem ketatanegaraan Indonesia dan hambatan-hambatan sosial-politik apa yang dapat muncul. Kajian ini akan menggunakan perbandingan hukum sebagai metoda.
\end{abstract}

Kata kunci:

hak konstitusional; keluhan konstitusional; Mahkamah Konstitusi.

\section{Pendahuluan}

Dua isu pokok yang selalu menjadi tolak ukur perkembangan prinsipprinsip negara hukum yaitu masalah pembatasan kekuasaan dan perlindungan hak asasi manusia. Kepentingan paling mendasar dari setiap warga negara adalah perlindungan terhadap hak-haknya sebagai manusia. ${ }^{1}$ Gagasan konstitusi sebagai alat pembatas kekuasaan tidak dapat dipisahkan dari gagasan perlindungan hak

\footnotetext{
${ }^{1}$ Achmad Edi Subiyanto, Perlindungan Hak Konstitusional Melalui Pengaduan Konstitusional, Vol 8 No. 5, Jurnal Konstitusi, Oktober 2011, hlm 708
} 
asasi manusia, negara demokratis dan negara hukum. Oleh karena itu, hak asasi manusia merupakan salah satu materi inti dari naskah undang-undang dasar negara modern. Keterkaitan antara konstitusi dengan hak asasi manusia dapat dilihat dari perkembangan sejarah. Perjuangan perlindungan hak asasi manusia selalu terkait dengan perkembangan upaya pembatasan dan pengaturan kekuasaan yang merupakan ajaran konstitusionalisme. Konstitusi merupakan kristalisasi normatif atas tugas negara dalam memberikan perlindungan hak asasi manusia dan melaksanakan pemerintahan berdasarkan kedaulatan rakyat disertai batas-batas kekuasaan secara hukum yang diarahkan bagi kepentingan dan kemaslahatan rakyat secara keseluruhan. ${ }^{2}$

Mahkamah Konstitusi merupakan lembaga yudikatif yang sejak awal pembentukannya sampai dengan saat ini memiliki beberapa wewenang yaitu: menguji undang-undang terhadap UUD 1945, memutus sengketa kewenangan lembaga negara yang kewenangannya diberikan oleh UUD 1945, memutus pembubaran partai politik, memutus perselisihan tentang hasil pemilihan umum, dan memberikan putusan atas pendapat Dewan Perwakilan Rakyat mengenai dugaan pelanggaran oleh Presiden dan/atau Wakil Presiden menurut UndangUndang Dasar. Berdasarkan kewenangan Mahkamah Konstitusi tersebut, ketika terdapat pelanggaran terhadap hak asasi warga negara yang dijamin dalam konstitusi (dan pelanggarannya terdapat dalam ketentuan aturan hukum atau regulasi) dapat diluruskan melalui salah satu kewenangannya yaitu mekanisme constitutional review. Namun, masih terdapat satu hal yang belum terakomodir dalam kewenangan Mahkamah Konstitusi yang diberikan oleh UUD 1945, yaitu terkait penanganan terhadap pengaduan atau keluhan konstitusi oleh rakyat (constitutional complaint). ${ }^{3}$

Di Indonesia permohonan constitutional complaint diberlakukan secara terbatas, yaitu apabila keberadaan undang-undang yang didalilkan dianggap telah

\footnotetext{
2 Mahfud M.D., Demokrasi dan Konstitusi di Indonesia, Rineka Cipta, Jakarta, 2003, hlm 142

3 Solidaman Bertho Plaituka, Constitutional Complaint Dalam Rangka Penegakan Hak Asasi Manusia di Republik Indonesia, Vol. 23 No.1, Jurnal Media Hukum, Juni 2016, hlm 111
} 
mengusik hak-hak konstitusional warga negara (melalui judicial review) ${ }^{4}$. Permohonan dapat diajukan melalui Mahkamah Konstitusi. Pelanggaran hak sebagaimana tercantum di dalam UUD 1945, bersumber dari tindakan konkrit aparatur birokrasi pemerintah, karena itu menentukan pelanggaran hak-hak konstitusional hanya sebatas pada undang-undang (judicial review), justru membiarkan pelanggaran konstitusi berlangsung terus tanpa ada pihak yang dapat menghentikannya. ${ }^{5}$ Terdapat banyak jalan dan kemungkinan terjadinya pelanggaran hak-hak konstitusional warga negara, baik oleh tindakan dari penguasa maupun oleh pihak-pihak lain.

Belum adanya perlindungan konstitusional berpotensi memunculkan celah hukum yaitu berupa kekosongan aturan hukum ataupun mekanisme hukum yang dapat memicu terjadinya pelanggaran hak-hak dasar berupa suatu produk peraturan perundang-undangan ataupun tindakan eksekutif yang mencederai hak-hak dasar warga negara yang telah diatur di dalam konstitusi. Banyak constitutional complaint yang diajukan ke Mahkamah Konstitusi tidak dapat terselesaikan. ${ }^{6}$ Mahkamah Konstitusi kerap melakukan sidang berkaitan dengan pelanggaran terhadap konstitusi yang masuk dalam kewenangannya. Namun terdapat hal mendasar yang masih mengganjal di benak pencari keadilan, yaitu belum terbukanya fungsi Mahkamah Konstitusi selaku lembaga yang dapat menampung dan menyalurkan keluh kesah (personal grievance) atau constitutional complaint sebagai upaya yang luar biasa dalam mempertahankan hak-hak konstitusional bagi setiap warga negara. ${ }^{7}$

Berdasarkan tulisan-tulisan mengenai constitutional complaint yang telah ada dan pendapat beberapa pakar hukum tata negara yang menyetujui bahwa penanganan kasus constitutional complaint penting untuk diberikan kepada

\footnotetext{
${ }^{4}$ Jimly Asshiddiqie, Menuju Negara Hukum yang Demokratis, Sekretariat Jenderal dan Kepaniteraan Mahkamah Konstitusi, Jakarta, 2008, hlm. 77

5 Id., hlm., 78

6 Menurut I Dewa Gede Palguna, setidaknya terdapat 30 perkara judicial review dari tahun 20032010 yang secara subtansial berisi gugatan konstitusional (constitutional complaint).

7 Zaka Firma Aditya, Kewenangan Mahkamah Konstitusi Dalam Menyelesaikan Perkara Constitutional complaint Berdasarkan Undang-Undang Dasar Tahun 1945, Vol. 3 No. 1, Unnes Law Journal, 2014, hlm 39
} 
Mahkamah Konstitusi, penulis menyetujui gagasan untuk menetapkan penanganan perkara constitutional complaint ke dalam kewenangan Mahkamah Konstitusi. Dalam hal ini bukan melalui amandemen UUD 1945 ataupun perubahan UU Mahkamah Konstitusi, melainkan melalui judicial interpretation oleh Mahkamah Konstitusi. Tulisan ini tidak hanya akan membahas mengenai penilaian terhadap urgensi gagasan untuk menetapkan penanganan perkara constitutional complaint ke dalam kewenangan Mahkamah Konstitusi yang dilihat dari sisi perbandingan dengan negara Jerman dan Korea serta pandangan pro dan kontra dari beberapa pakar hukum tata negara Indonesia, namun juga akan membahas dengan lebih mendalam mengenai objek constitutional complaint yang sesuai dengan ketatanegaraan Indonesia, dan hambatan pelaksanaan constitutional complaint yang dapat terjadi dari sisi sosial dan politik di Indonesia.

\section{Pembahasan}

\section{Hak Konstitusional Sebagai Bagian dari Konstitusi}

UUD 1945 tidak memberikan pengertian tentang hak konstitusional. Dalam hukum positif Indonesia, istilah hak konstitusional baru muncul dalam UU No. 24 Tahun 2003 dan diberi pengertian sebagai "hak-hak yang diatur dalam UndangUndang Dasar Negara Republik Indonesia Tahun 1945".8 Hak-hak yang diatur dalam UUD 1945 tersebut mencakup baik hak-hak yang tergolong ke dalam hak warga negara (citizen's rights) maupun hak-hak yang tergolong ke dalam hak asasi manusia (human rights). Hak-hak yang tergolong ke dalam hak warga negara diatur dalam Bab X yang rumusannya dimulai dengan kata-kata "segala warga negara" atau "tiap-tiap warga negara" atau "setiap warga negara", sedangkan hakhak yang tergolong ke dalam hak asasi manusia diatur dalam Bab XA yang rumusannya dimulai dengan kata-kata "setiap orang”. Dengan demikian, hak konstitusional mencakup citizen rights maupun human rights, sehingga secara

\footnotetext{
8 Pasal 51 ayat (1) jo Penjelasan Pasal 51 ayat (1) UU Nomor 24 Tahun 2003 Tentang Mahkamah Konstitusi
} 
umum hak konstitusional dapat diberikan pengertian sebagai hak-hak yang dijamin oleh konstitusi atau undang-undang dasar. ${ }^{9}$

Hak konstitusional dapat juga dilihat secara timbal balik dengan kewajiban konstitusional negara. Setiap kewajiban konstitusional negara yang disebut dalam UUD 1945, menyimpulkan adanya hak konstitusional sebagai bagian yang tidak dapat dipisahkan dari padanya atau yang melekat pada kewajiban negara tersebut. Misalnya kewajiban negara untuk mengalokasi dana pendidikan sebesar dua puluh persen dari APBN. Hal tersebut menimbulkan hak konstitusional bagi warga negara. Oleh karena itu di samping hak konstitusional yang dapat dilihat secara tegas dituliskan dalam konstitusi, ada juga yang harus disimpulkan dari kewajiban negara karena antara hak dan kewajiban satu dengan lain tidak dapat dipisahkan. ${ }^{10}$

Hak konstitusional yang dicantumkan dalam konstitusi atau undangundang dasar akan menjadi bagian dari konstitusi atau undang-undang dasar sehingga seluruh cabang kekuasaan negara wajib menghormatinya. Oleh sebab itu, pengakuan dan penghormatan terhadap hak-hak konstitusional sebagai bagian dari konstitusi sekaligus juga berarti pembatasan terhadap kekuasaan negara. Selanjutnya, sebagai bagian dari konstitusi maka hak-hak konstitusional itu harus dilindungi, sehingga diperlukan suatu mekanisme untuk mewujudkan perlindungan atas hak konstitusional tersebut. Mekanisme atau jalan hukum bagi perlindungan terhadap hak konstitusional tersebut dapat berupa mekanisme yudisial (melalui proses peradilan) maupun non yudisial (di luar proses peradilan). ${ }^{11}$

Beberapa hal penting yang menjadi karakteristik hak konstitusional, yaitu: ${ }^{12}$

\footnotetext{
9 I Dewa Gede Palguna, Pengaduan Konstitusional Upaya Hukum terhadap Pelanggaran Hak- Hak Konstitusional Warga Negara, Sinar Grafika, Jakarta, 2013, hlm 38-39

10 Maruarar Siahaan, "Hak Konstitusional Dalam UUD 1945", ama.elsam.or.id/downloads/1322798965_HAK_KONSTITUSIONAL_DALAM_UUD_1945, diakses 27 Juli 2017

11 Supra no. 10, hlm 111-112.

12 Id., hlm., 136
} 
1. Hak konstitusional memiliki sifat fundamental karena dijamin oleh dan menjadi bagian dari konstitusi tertulis yang merupakan hukum fundamental;

2. Hak konstitusional merupakan bagian dari dan dilindungi oleh konstitusi tertulis, sehingga harus dihormati oleh seluruh cabang kekuasaan negara, baik legislatif, eksekutif, dan yudikatif;

3. Hak konstitusional yang bersifat fundamental mengakibatkan setiap tindakan organ negara yang bertentangan dengan atau melanggar hak itu harus dapat dinyatakan batal oleh pengadilan;

4. Perlindungan yang diberikan oleh konstitusi bagi hak konstitusional adalah perlindungan terhadap perbuatan negara atau pelanggaran oleh negara, bukan terhadap perbuatan atau pelanggaran oleh individu;

5. Hak konstitusional sebagai hak yang memiliki sifat fundamental merupakan pembatasan terhadap kekuasaan negara.

\section{Perspektif Penambahan Constitutional Complaint Dalam Kewenangan Mahkamah Konstitusi}

Mekanisme constitutional complaint atau dalam bahasa Jerman disebut verfassungsbeschwerde merupakan hak yang dimiliki oleh setiap orang atau kelompok tertentu untuk melakukan pernyataan sikap tidak setuju atau menolak terhadap perlakuan pemerintah terhadapnya. Artinya, orang atau kelompok tertentu tersebut merasa hak-hak konstitusionalnya dilanggar oleh pemerintah. Tujuan dari constitutional complaint adalah agar setiap orang atau kelompok tertentu memiliki kebebasan dan persamaan kedudukan dalam berpartisipasi dalam sebuah negara dan untuk menegakkan prinsip-prinsip demokrasi termasuk tanggung jawab mengenai perlindungan terhadap kekuatan konstitutional yang dimiliki oleh masyarakat. Constitutional complaint memberikan jaminan agar dalam proses menentukan dalam penyelenggaraan negara, baik dalam pembuatan perundang-undangan, proses administrasi negara, dan putusan peradilan tidak melanggar hak-hak konstitusional. ${ }^{13}$

\footnotetext{
${ }^{13}$ Vino Devanta Krisdanar, Menggagas Constitutional Complaint dalam Memproteksi Hak Konstitusional Masyarakat Mengenai Kehidupan dan Kebebasan Beragama di Indonesia, Vol. 7 No.3, Jurnal Konstitusi, 2010, hlm 190
} 
Bentuk perlindungan hak konstitusional melalui mekanisme pengadilan dapat dikelompokkan menjadi: ${ }^{14}$

a) Perlindungan hak konstitusional melalui pengadilan tata negara (c.q. mahkamah konstitusi);

b) Perlindungan hak konstitusional melalui pengadilan tata administrasi atau tata usaha negara;

c) Perlindungan hak konstitusional melalui pengadilan biasa (regular court);

d) Perlindungan hak konstitusional melalui pengadilan hak asasi manusia ad hoc.

Sedangkan bentuk perlindungan hak konstitusional melalui mekanisme non pengadilan terwujud dalam pembentukan institusi-institusi yang jika dilihat berdasarkan maksud pembentukan, kewenangan, dan aktivitasnya secara luas, dapat diartikan sebagai bentuk upaya perlindungan terhadap hak konstitusional warga negara, misalnya Ombudsman, Komisi Nasional Hak Asasi Manusia, Lembaga Perlindungan Saksi dan Korban, Komisi Penyiaran Indonesia, dan Komisi Pengawas Persaingan Usaha. ${ }^{15}$

Pengadilan Konstitusi Jerman adalah salah satu dari pengadilan konstitusi di dunia yang secara tegas memiliki wewenang constitutional complaint yang diatur dalam konstitusi, yaitu oleh Konstitusi Federal (Grundgesetz-GG), dan oleh Undang-Undang tentang Pengadilan Konstitusi Federal Jerman (Bundesverfassungsgerichtsgesetz-BVerfGG). Terdapat kesamaan penting antara Pengadilan Konstitusi Jerman dengan Mahkamah Konstitusi Republik Indonesia yaitu baik Indonesia dan Jerman berada dalam model constitutional review yang sama, yaitu model constitutional review Eropa dan secara tradisi hukum (legal tradition) Indonesia dan Jerman juga berada dalam tradisi hukum yang sama, yaitu tradisi civil law. Dalam tradisi civil law, kodifikasi memegang peranan penting sebagai sumber hukum dan kodifikasi tertinggi adalah konstitusi atau undang-undang dasar.

\footnotetext{
${ }^{14}$ Supra no. 10, hlm 152

${ }^{15}$ Id., hlm 164
} 
Pada mulanya, GG tidak mengatur secara eksplisit kewenangan Mahkamah Konstitusi Jerman untuk memutus perkara pengaduan konstitusional. Kewenangan tersebut secara tegas baru diberikan kemudian dalam Pasal 93 ayat (1) GG. ${ }^{16}$ Kewenangan memutus perkara pengaduan konstitusional tersebut diuraikan pada Pasal 93 ayat (1) angka 4a dan 4b GG ${ }^{17}$ yang dinyatakan sebagai berikut:

Pasal 93 ayat (1)

4a. on complaints of unconstitutionality, being filed by any person claiming that one of his basic rights or one of his rights under Article 20 IV or under Article 33, 38, 101, 103 or 104 has been violated by public authority;

4b.on complaints of unconstitutionality filed by communes or associations of communes on the ground that their right to selfgovernment under Article 28 has been violated by a statute other than a State [Land] statute open to complaint to the respective State [Land] constitutional court.

Dari ketentuan tersebut tampak bahwa subjek yang dapat mengajukan pengaduan ke Mahkamah Konstitusi Jerman adalah: 18

1. Perorangan jika hak-hak yang dilanggar oleh suatu pejabat publik (public authority) adalah hak-hak dasar atau hak-hak yang diatur dalam Pasal 20IV atau Pasal 33, 38,101, 103 atau 104 GG;

2. Komune atau asosiasi komune jika hak mereka atas pemerintahan sendiri menurut Pasal 28 GG dilanggar oleh suatu undang-undang selain undang-undang negara bagian yang terbuka untuk diajukan pengaduan kepada Mahkamah Konstitusi negara bagian.

Ketentuan yang merupakan bagian dari hukum acara mengenai pengaduan konstitusional diatur dalam Pasal 90 sampai dengan Pasal 95 BverfGG. Ketentuan Pasal 90 BverfGG pada intinya menyatakan bahwa pada dasarnya pengaduan konstitusional baru dapat diajukan jika tidak tersedia upaya hukum lagi atau semua upaya hukum yang ada telah dilalui. Namun, ketentuan tersebut dapat dikecualikan jika pengaduan tersebut mengandung relevansi umum (of general relevance) atau bila penyelesaian melalui pengadilan lain ditempuh terlebih

\footnotetext{
16 Pasal 93 ayat (1) angka 4a dan 4b baru dimasukkan pada Amandemen ke-19 (29 Januari 1969)

${ }^{17}$ Ketentuan ini kembali dipertegas dalam Pasal 13 angka 8a UU tentang MK Federal (BverfGG)

18 Supra no.10, hlm 415
} 
dahulu akan menimbulkan suatu kerugian serius dan tak terhindarkan pada pihak pemohon pengaduan. Dalam keadaan demikian Mahkamah Konstitusi Jerman dapat segera menjatuhkan putusan atas perkara pengaduan konstitusional meskipun semua upaya hukum yang tersedia belum ditempuh. Selanjutnya pasal 92 BverGG menyatakan bahwa alasan pengajuan pengaduan konstitusional harus menjelaskan hak-hak yang didalilkan telah dilanggar atau perbuatan atau kelalaian dari organ atau pejabat yang didalilkan telah melakukan pelanggaran tersebut. ${ }^{19}$ Hal yang perlu diperhatikan adalah dalam hal-hal yang sangat khusus, undang-undang dapat menjadi objek pengaduan konstitusional apabila suatu norma undang-undang langsung merugikan hak konstitusional (basic rights) dari pengadu. $^{20}$

Di Asia, Korea Selatan adalah negara yang sudah lama menerapkan constitutional complaint sebagai salah satu wewenang pengadilan konstitusinya. Wewenang ini diberikan berdasarkan Pasal 68 ayat (1) dan (2) The Constitutional Court Act of Korea yang menyatakan: ${ }^{21}$

(1) Any person who claims that his basic right which is guaranteed by the Constitution has been violated by an exercise or non-exercise of governmental power may file a constitutional complaint, except the judgments of the ordinary courts, with the Constitutional Court: Provided, That if any relief process is provided by other laws, no one may file a constitutional complaint without having exhausted all such processes"

(2) If the motion made under Article 41 (1) for adjudication on constitutionality of statutes is rejected, the party may file a constitutional complaint with the Constitutional Court. In this case, the party may not repeatedly move to request for adjudication on the constitutionality of statutes for the same reason in the procedure of the case concerned."

Berdasarkan ketentuan tersebut, pihak yang dapat mengajukan permohonan pengaduan konstitusional ke Mahkamah Konstitusi Korea adalah pertama, setiap orang yang menganggap hak-hak dasarnya yang dijamin oleh Konsitusi telah terlanggar oleh suatu tindakan pemerintah atau oleh tidak

\footnotetext{
${ }^{19} \mathrm{Id}$., hlm 416

${ }^{20}$ Sebagaimana diatur dalam Pasal 93 ayat (3) BVerlGG

${ }^{21}$ Id., hlm 465
} 
bertindaknya pemerintah atau langsung oleh undang-undang yang dibuat oleh legislatif (legislative act); kedua pihak-pihak dalam proses peradilan di pengadilan biasa yang permintaannya agar pengadilan yang bersangkutan mengajukan permohonan kepada Mahkamah Konstitusi Korea untuk menguji konstitusionalitas undang-undang yang berlaku dalam proses peradilan itu ditolak oleh pengadilan yang dimaksud. ${ }^{22}$

Sama halnya dengan di Jerman, pengaduan konstitusionalitas di Korea juga baru dapat dilakukan jika semua upaya hukum lain yang tersedia telah dilalui. Akan tetapi, ada tiga hal yang membedakan yaitu (1) di Korea legal person (badan hukum) tidak dimungkinkan untuk mempunyai standing dalam pengadilan konstitusional melainkan hanya natural person; (2) di Korea putusan pengadilan biasa tidak dapat menjadi objek pengaduan; dan (3) di Korea tidak dimungkinkan untuk menjadikan norma undang-undang sebagai objek pengaduan, yang dikecualikan dari keharusan untuk menempuh jalan hukum lain terlebih dahulu, meskipun norma undang-undang itu langsung merugikan hak konstitusional. ${ }^{23}$

Berdasarkan perbandingan dengan kedua negara tersebut, penulis menyetujui pandangan dari Palguna yang menyatakan bahwa di negara penganut pengujian konstitusional seperti Jerman dan Korea Selatan, pengaduan konstitusional merupakan salah satu mekanisme penting dalam melindungi hakhak konstitusional warga negara. Dengan demikian praktik pengaduan konstitusional di negara-negara tersebut memperkuat asumsi bahwa pemberian kewenangan untuk mengadili perkara pengaduan konstitusional kepada Mahkamah Konstitusi Indonesia merupakan kebutuhan. ${ }^{24}$ Lebih lanjut Palguna menyatakan bahwa secara khusus dari praktik pengaduan konstitusional di Jerman dan Korea pelajaran yang dapat dipetik adalah bahwa pada kondisi tertentu, tidak lagi dapat dibedakan secara substansial antara pengaduan konstitusional dan pengujian undang-undang yaitu ketika tindakan atau

22 Id., hlm 465-466

23 Id.

24 Id., hlm 483-484 
perbuatan yang diadukan untuk diuji konstitusionalitasnya adalah legislative act, yaitu undang-undang. 25

Dalam praktik di Indonesia, meskipun judicial review telah menjadi kewenangan Mahkamah Konstitusi namun hal ini hanya terbatas pada produk DPR (undang-undang) sehingga tindakan-tindakan (kebijakan) baik pemerintah (eksekutif), legislatif, atau yudikatif yang berpotensi merugikan hak warga yang telah dijamin oleh konstisusi khususnya hak yang bersifat fundamental rights belum terlindungi secara baik. Pada negara yang menganut paham negara demokrasi, seperti halnya di Indonesia, mekanisme constitusional complaint menjadi sangat penting untuk diatur. Hal tersebut dilakukan dalam rangka menjamin hak-hak konstitusional warga negara sebagaimana tercantum dalam UUD 1945 pasal 28A sampai pasal 28J. Mekanisme ini diperlukan karena hak konstitusional masyarakat tidak hanya berpotensi dilanggar dengan berlakunya sebuah Undang-Undang sehingga hanya disediakan mekanisme judicial review, namun hak warganegara tentunya juga sangat berpotensi dirugikan dengan adanya tindakan (kebijakan) yang dikeluarkan oleh kekuasaan eksekutif (pemerintah), DPR (legislatif), serta pelanggaran yang dikeluarkan oleh kekuasaan kehakiman. ${ }^{26}$

Gagasan membentuk Mahkamah Konstitusi lahir dari kebutuhan untuk terselenggaranya gagasan pengujian konstitusional. Sementara itu salah satu tugas pengujian konstitusional adalah untuk melindungi warga negara dari penyalahgunaan kekuasaan oleh lembaga-lembaga negara. Pengaduan konstitusional adalah salah satu wujud perlindungan hak konstitusional melalui mekanisme pengadilan dimana pengadilan yang dimaksud di sini adalah pengadilan yang secara khusus diberi fungsi untuk melaksanakan constitutional review, yaitu Mahkamah Konstitusi. Semua negara yang mengadopsi mekanisme pengaduan konstitusional dan melembagakan pengujian konstitusionalnya secara tersentralisasi, yaitu dengan mendirikan mahkamah konstitusi, pasti memberikan

\footnotetext{
25 Id., hlm 485

${ }^{26}$ Rahmat Muhajir Nugroho, Urgensi Pengaturan Perkara Constitutional Complaint dalam Kewenangan Mahkamah Konstitusi, Vol.7 No.1, Jurnal Ilmu Hukum Novelty, Februari 2016, hlm 18
} 
kewenangan mengadili perkara pengaduan konstitusional kepada mahkamah konstitusi. Berdasarkan hal tersebut dapat dikatakan bahwa pengaduan konstitusional sebagai mekanisme perlindungan hak-hak konstitusional tidak dapat dipisahkan dari hakikat keberadaan mahkamah konstitusi sebagai lembaga yang sengaja didesain untuk melaksanakan fungsi constitutional review, dan melekat dalam fungsi mahkamah konstitusi untuk melaksanakan pengujian konstitusional. ${ }^{27}$

Dalam praktik, banyak perkara yang diajukan ke Mahkamah Konstitusi yang secara formal dalam bentuk pengujian undang-undang, tetapi secara substansial termasuk constitutional complaint. ${ }^{28}$ Kasus-kasus yang secara subtansial merupakan constitutional complaint tersebut tidak mungkin diminta menunggu sampai adanya kemauan dan tindakan politik untuk melaksananakan perubahan terhadap UU Mahkamah Konstitusi, apalagi terhadap UUD 1945. Kasus-kasus tersebut secara teoritik memiliki potensi untuk selalu muncul pada masa yang akan datang karena adanya kemungkinan-kemungkinan: ${ }^{29}$

1. Seorang warga negara menganggap hak konstitusionalnya telah dirugikan oleh perbuatan satu pejabat publik yang lahir dari kekeliruan menafsirkan maksud undang-undang; atau, satu pejabat publik justru tidak melakukan tindakan yang seharusnya dilakukan sesuai dengan perintah atau maksud undangundang sehingga merugikan hak konstitusional seorang warga negara. Sementara itu tidak tersedia upaya hukum yang dapat ditempuh oleh warga negara yang bersangkutan atau semua upaya hukum yang ada telah dilalui. Dalam hal ini, Undang-Undang tidak merugikan hak konstitusional warga negara sehingga tidak bertentangan dengan konstitusi, akan tetapi pelaksanaannya telah ditafsirkan secara keliru atau tidak dilaksanakan sehingga merugikan hak-hak konstitusional warga negara;

2. Seorang warga negara menganggap hak konstitusionalitasnya telah dirugikan oleh ketetapan MPR atau ketetapan MPRS yang hingga saat ini masih berlaku.

27 Supra no. 10, hlm 309

28 Supra no. 27, hlm 17-18

${ }^{29}$ Supra no. 10, hlm 609 
Dalam hal ini timbul persoalan apabila ketetapan MPR tersebut bersifat regeling, meskipun setelah perubahan UUD 1945, MPR tidak memiliki kewenangan membuat ketetapan yang bersifat regeling. Apabila hal itu terjadi maka mekanisme pengujiannya akan sangat sulit karena sesuai dengan hierarkinya di dalam Undang-Undang No. 12 tahun 2011 tentang Pembentukan Peraturan Perundang-Undangan, Ketetapan MPR berada dibawah UUD 1945 dan di atas Undang-Undang.

3. Seorang warga negara menganggap hak konstitusionalnya telah dirugikan oleh berlakunya peraturan perundang-undangan di bawah Undang-Undang. Hal ini terjadi karena UUD 1945 tidak secara eksplisit menyatakan siapa yang berwenang mengadili atau menguji jika satu peraturan perundang-undangan di bawah Undang-Undang bertentangan bukan dengan Undang-Undang melainkan dengan UUD 1945.

Mahfud M.D. juga menyatakan kemungkinan constitutional complaint untuk ditambahkan menjadi kewenangan Mahkamah Konstitusi jika kelak ada amandemen lanjutan atas UUD 1945. Paling tidak ada tiga cakupan yang dimuat oleh rezim constitutional complaint, yaitu: ${ }^{30}$

1. Pengajuan perkara ke Mahkamah Konstitusi atas pelanggaran hak konstitusional yang tidak ada instrumen hukum untuk memperkarakan atau tidak tersedia lagi jalur penyelesaian hukum (peradilan);

2. Adanya peraturan perundang-undangan di bawah Undang-Undang yang langsung melanggar isi konstitusi, tetapi tidak secara jelas melanggar peraturan perundang-undangan yang lebih tinggi di bawah UUD 1945;

3. Putusan pengadilan yang melanggar hak konstitusional padahal sudah mempunyai kekuatan hukum yang tetap dan tidak dapat dilawan lagi dengan upaya hukum ke pengadilan yang lebih tinggi, contohnya putusan kasasi yang telah memiliki kekuatan hukum tetap tetapi merugikan hak konstitusional seseorang.

Seperti yang telah disebutkan sebelumnya bahwa di Indonesia belum memiliki mekanisme constitutional complaint, tetapi hanya memiliki mekanisme

\footnotetext{
${ }^{30}$ Moh. Mahfud MD, Konstitusi dan Hukum Dalam Kontroversi Isu, Rajawali Press, Jakarta, 2009, hlm. 289.
} 
constitutional review (judicial review), maka objek permohonan/gugatan (produk hukum) yang dianggap melanggar hak konstitusional warga negara juga hanya sebatas undang-undang baik secara keseluruhan maupun pasal-pasal dari suatu Undang-Undang yang dianggap bertentangan dengan Undang-Undang Dasar Tahun 1945. Namun, seperti yang telah dijelaskan sebelumnya bahwa secara substansi banyak pemohon pengajuan constitutional review yang di dalamnya terkandung permohonan constitutional complaint.

Gagasan atau ide memasukkan mekanisme constitutional complaint di Indonesia telah muncul ketika Komisi Konstitusi membuat draf sandingan Perubahan UUD 1945, yaitu: “... Mahkamah Konstitusi berhak memeriksa constitutional complaint atau constitution complaint dari warga negara”. Komisi Konstitusi mengusulkan agar Pasal 24C Ayat (1) hasil Perubahan Ketiga UUD 1945 ditambah dengan pengaturan mengenai constitutional complaint. ${ }^{31}$ Pada saat pembahasan Perubahan UUD 1945 telah muncul usulan constitutional complaint sebagai salah satu kewenangan Mahkamah Konstitusi sebagaimana dikemukakan I Dewa Gede Palguna dalam rapat Pleno Panitia Ad Hoc MPR RI (Perubahan UUD 1945) tahun 2000 (MPR RI, Risalah Rapat, tanggal 8 Juni 2000). Usulan tersebut tidak disetujui dengan berbagai pertimbangan, antara lain karena tujuan utama dibentuknya Mahkamah Konstitusi adalah sebagai lembaga judicial review Undang-Undang terhadap UUD 1945, sehingga menghindari adanya penumpukan perkara, seperti dalam praktik yang terjadi di Mahkamah Konstitusi Jerman. ${ }^{32}$

Dalam perkembangan selanjutnya, gagasan untuk menetapkan penanganan perkara constitutional complaint ke dalam kewenangan Mahkamah Konstitusi menjadi isu tersendiri dan menimbulkan berbagai reaksi dari kalangan pakar hukum tata negara. Menurut Jimly Ashiddiqie, adanya mekanisme constitusional complaint bisa membuat Mahkamah Konstitusi berbenturan dengan pengadilan Hak Asasi Manusia apabila ada seseorang yang merasa dirugikan hak-hak asasinya. Hal seperti ini menimbulkan suatu ketidakpastian hukum seperti halnya

\footnotetext{
31 Supra no. 2, hlm 716

32 Hamdan Zoelva, Constitutional Complaint dan Constitutional Question dan Perlindungan Hakhak Konstitusional Warga Negara, Vol.19, No.1, Jurnal Media Hukum, Juni 2012, hlm 159
} 
pengadilan terhadap perkara korupsi yang bisa diadili di pengadilan umum maupun pengadilan tindak pidana korupsi. ${ }^{33}$

Menurut Huda, pada saat ini kewenangan Mahkamah Konstitusi tidak perlu ditambah dengan constitutional complaint, sebab Mahkamah Konstitusi sudah menangani perkara yang sangat banyak terutama tentang penyelesaian sengketa pemilihan kepala daerah dan fokus pada penyelesaian perkara pengujian undangundang dengan baik. Pengaturan kewenangan constitutional complaint bukan kebutuhan yang mendesak pada saat ini. Mahkamah Konstitusi sebaiknya menata diri terlebih dahulu untuk mengembalikan kepercayaan masyarakat. Setelah itu jika kepercayaan masyarakat sudah pulih dan kondisinya sudah memungkinkan, constitutional complaint bisa saja dimasukkan dalam kewenangan Mahkamah Konstitusi. Jika constitutional complaint akan dimasukkan ke dalam kewenangan Mahkamah Konstitusi, maka harus dilakukan melalui amandemen konstitusi, sebab hal itu merupakan kewenangan baru yang berbeda dengan empat kewenangan yang telah ada. Pengaturan kewenangan constitutional complaint tidak dapat dilakukan melalui revisi Undang-Undang Mahkamah Konstitusi, karena tidak memiliki landasan hukumnya. ${ }^{34}$

Berbeda dengan pendapat Sulardi yang menyatakan bahwa sejauh ini ada persoalan keadilan yang belum terselesaikan. Artinya terdapat berbagai kasus yang tidak mampu diselesaikan melalui jalur pengadilan, karena tidak masuk lingkup kewenangan lembaga-lembaga pengadilan yang ada. Oleh karena itu, constitutional complaint merupakan alternatif yang dapat digunakan oleh warga negara untuk memperoleh keadilan tersebut. Ketika ada persoalan yang secara eksplisit tidak masuk dalam kewenangan Mahkamah Konstitusi, maka Mahkamah Konstitusi harus berani memutuskan persoalan itu sebagai bagian dari konvensi ketatanegaraan. Jika ingin memasukkan constitutional complaint ke dalam kewenangan Mahkamah Konstitusi, tidak perlu amandemen konstitusi dan revisi

\footnotetext{
${ }^{33}$ Supra no. 14, hlm 189

34 Supra no. 27, hlm 20
} 
Undang-Undang Mahkamah Konstitusi, artinya tidak perlu ada legal formal dan cukup melalui konvensi ketatanegaraan. ${ }^{35}$

Pendapat senada dari Nanik Prasetyoningsih yang menyatakan constitutional complaint urgen untuk diselenggarakan mengingat banyak persoalan yang tidak mampu diselesaikan oleh lembaga-lembaga negara yang lain, terutama di pengadilan dan pemerintah. Constitutional complaint bisa menjadi saluran bagi orang yang sudah mengajukan perkaranya melalui pengadilan tetapi belum mendapatkan kepuasan karena merasa belum mendapatkan keadilan. Kewenangan constitutional complaint tidak perlu secara eksplisit dimasukkan ke dalam norma hukum, tetapi dengan cara melakukan perluasan makna judicial review sebagaimana yang diatur dalam Pasal 56 dan 57 UU No. 24 Tahun 2003. ${ }^{36}$

Berdasarkan perbedaan pendapat para ahli hukum tata negara di atas, terlihat jelas bahwa terdapat pro dan kontra mengenai wacana memasukkan constitutional complaint menjadi wewenang Mahkamah Konstitusi, karena wewenang tersebut tidak ditemukan dalam UUD 1945 secara eksplisit. Sebagian ahli berpendapat bahwa pemberian wewenang mengadili constitutional complaint kepada Mahkamah Konstitusi tidak harus melalui perubahan UUD 1945. Hal itu cukup dilakukan melalui revisi Undang-Undang Mahkamah Konstitusi, dengan memasukkan pengaturan eksplisit soal itu, sehingga kewajiban negara untuk melindungi hak asasi warga negaranya dapat diwujudkan. Pendapat ini memiliki kelemahan, karena masalah legitimasi yang tidak kuat, disebabkan konstitusi tidak secara eksplisit memberi wewenang demikian pada Mahkamah Konstitusi. Para ahli lain berpendapat bahwa Mahkamah Konstitusi hanya dapat mengadili constitutional complaint melalui pengaturan eksplisit dalam undang-undang dasar, sehingga hanya dapat dilakukan melalui perubahan undang-undang dasar. ${ }^{37}$

Penulis menyetujui pendapat Palguna yang menyatakan bahwa penambahan wewenang constitutional complaint melalui revisi UU Mahkamah

\footnotetext{
${ }^{35}$ Id.

${ }^{36} \mathrm{Id}$.

${ }^{37}$ Supra no. 33, hlm 162
} 
Konstitusi dapat menimbulkan masalah konstitusional, karena UUD 1945 memberikan wewenang limitatif terhadap Mahkamah Konstitusi. Demikian juga, penambahan wewenang melalui perubahan UUD 1945 adalah sesuatu yang sangat sulit dilakukan, karena untuk melakukan amandemen membutuhkan biaya serta waktu yang sangat lama, ditambah lagi gejolak perpolitikan di Indonesia yang masih belum stabil menyebabkan perubahan limitatif Pasal 24C UUD 1945 sangat sulit untuk dilaksanakan. Perubahan terhadap UUD 1945 bukanlah hal yang mudah, baik secara politik maupun prosedural. ${ }^{38}$

Selanjutnya Palguna juga menyatakan bahwa jika Mahkamah Konstitusi ingin memiliki kewenangan mengadili perkara constitutional complaint tanpa melalui perubahan formal UUD 1945, dapat dilakukan dengan dua cara: ${ }^{39}$

1. melalui legislative interpretation, dimana pembentuk undang-undang memberikan penafsiran otentik terhadap salah satu kewenangan yang secara tegas disebutkan dalam Pasal 24C ayat (1) UUD 1945 yaitu kewenangan "menguji undang-undang terhadap Undang-Undang Dasar." Tegasnya, dalam pengertian "menguji undang-undang terhadap Undang-Undang Dasar" dianggap tercakup pula pengujian konstitusionalitas tindakan atau kelalaian pejabat publik yang dianggap bertentangan dengan undang-undang dasar. Namun cara ini mempunyai kelemahan dimana untuk dapat melakukan legislative interpretation terhadap Pasal 24C ayat (1) UUD 1945 maka terlebih dahulu harus dilakukan perubahan terhadap Undang-Undang Mahkamah Konstitusi dan hal tersebut, terutama secara politik tetap tidak mudah untuk dilakukan.

2. melalui judicial interpretation oleh Mahkamah Konstitusi atas constitutional complaint.

Berdasarkan hal-hal tersebut, penulis menyetujui bahwa pemberian kewenangan constitutional complaint kepada Mahkamah Konstitusi akan lebih efektif tanpa melakukan amandemen terhadap UUD 1945 ataupun perubahan Undang-Undang Mahkamah Konstitusi, namun melalui judicial interpretation oleh

38 Supra no. 10 , hlm. 583-584

39 Supra no. 10 , hlm. 600 
Mahkamah Konstitusi. Hal itu dapat dilakukan dengan pengembangan putusanputusan Mahkamah Konstitusi melalui perluasan penafsiran atas kewenangan pengujian undang-undang yang telah ada dalam UUD 1945. Mahkamah Konstitusi bisa membuat interpretasi dinamis dan luas atas hak konstitusional dan kedudukan hukum dari penggugat.

Sebagai dasar argumen tersebut, penulis mengutip pendapat Palguna yang menyatakan bahwa jika Mahkamah Konstitusi RI menganut paham original intent dalam menafsirkan konstitusi, maka tidak mungkin kewenangan mengadili perkara pengaduan konstitusional dapat dilakukan. Sebab, bukan saja karena kewenangan tersebut tidak disebutkan secara eksplisit dalam undang-undang dasar, tetapi juga karena menurut sejarahnya tidak ditemukan keterangan yang menunjukkan adanya maksud penyusun UUD 1945 untuk memberikan kewenangan mengadili perkara pengaduan konstitusional pada Mahkamah Konsitusi RI. Namun, jika pendirian demikian yang dianut berarti Mahkamah Konstitusi RI telah membiarkan terjadinya pelanggaran terhadap hak konstitusional warga negara tanpa berusaha melakukan tindakan apapun, padahal perlindungan terhadap hak konstitusional merupakan syarat yang tidak dapat ditiadakan bagi keberadaan negara hukum yang menjadi salah satu landasan utama UUD 1945.40

Lebih jauh, salah satu tugas seluruh mahkamah konstitusi di seluruh dunia adalah melindungi hak-hak konstitusional warga negara, yang merupakan bagian dari pelaksanaan constitutional review. Hal ini berarti secara teoritik kewenangan mahkamah konstitusi untuk mengadili perkara pengaduan konstitusional telah melekat pada fungsi tersebut. Hal ini juga berlaku kepada Mahkamah Konstitusi RI sebagai organ konstitusi yang sengaja dibentuk oleh UUD 1945 untuk menjamin negara hukum, di mana salah satu cirinya adalah terlindunginya hak-hak konstitusional secara maksimum. ${ }^{41}$

\section{Objek Constitusional Complaint dalam Sistem Ketatanegaraan Indonesia}

\footnotetext{
40 Id., hlm 613-614

41 Id., hlm 614
} 
Dalam membicarakan objek yang dapat dimohonkan constitusional complaint, maka bagian ini akan membahas mengenai peristiwa dan atau bentuk norma hukum seperti apa yang dapat diajukan constitutional complaint. Lebih jauh, akan dibahas mengenai dalam hal seperti apa constitutional complaint dapat berperan untuk melindungi hak konstitusional warga negara. Dari segi kepada siapa suatu norma ditujukan, norma hukum dapat dibagi menjadi dua yaitu norma hukum umum dan individual. Norma hukum umum adalah suatu norma hukum yang ditujukan untuk orang banyak (addressatnya umum) dan tidak tertentu sedangkan norma hukum individual adalah norma hukum yang ditujukan atau dialamatkan hanya kepada seseorang, beberapa orang atau banyak orang yang telah tertentu atau dengan kata lain dapat didefinisikan siapakah orang atau golongan orang tersebut. ${ }^{42}$ Contoh dari norma hukum umum adalah UndangUndang, peraturan daerah, peraturan menteri (aturan-aturan ini sering dikenal dengan istilah regeling), sedangkan contoh dari norma hukum khusus adalah keputusan (beschikking) yang berasal dari lembaga eksekutif 43 . Semua bentuk norma hukum tersebut dapat dilakukan upaya constitutional complaint.

Pengujian produk regeling termasuk wilayah kerja pengujian dalam konteks hukum tata negara, yakni berdasarkan ketentuan Pasal 24C ayat (1) UUD 1945 yang berwenang menguji Undang-Undang terhadap UUD 1945 adalah Mahkamah Konstitusi, sedangkan berdasarkan pasal 24A UUD 1945 yang berhak menguji peraturan perundang-undangan dibawah Undang-Undang adalah Mahkamah Agung. Penerapan constitutional complaint terhadap pengujian norma hukum tersebut adalah terhadap peraturan perundang-undangan di bawah Undang-Undang yang diajukan ke Mahkamah Agung. Mahkamah Agung tidak akan memeriksa peraturan undang-undang dibawah Undang-Undang dengan menggunakan UUD 1945 sebagai alat ujinya karena Mahkamah Agung hanya menguji legalitas peraturan perundang-undangan (judicial review on the legality of

\footnotetext{
42 Maria Farida, Ilmu Perundang-Undangan I: Jenis, Fungsi dan Materi Muatan, Kanisius, Yogyakarta, 2007, hlm. 26-27.

43 Supra no. 14, hlm 196
} 
regulation). ${ }^{44}$ Dalam hal ini constitutional complaint mengambil peranannya untuk menilai apakah putusan dari Mahkamah Agung tersebut melanggar hak-hak konstitusional masyarakat atau tidak, atau menilai peraturan perundangundangan di bawah Undang-Undang yang secara nyata tidak melanggar peraturan perundang-undangan di atasnya namun secara langsung melanggar UUD 1945.45

Dalam konteks demikian, pengaduan konstitusional mempunyai peranan sebagai bagian dari pengujian konstitusionalitas norma hukum. Secara konsep hukum, apabila pengaduan ditujukan kepada produk legislatif, yaitu UndangUndang, dinamakan pengujian Undang-Undang (judicial review), sedangkan jika pengaduan ditujukan terhadap perbuatan atau kelalaian cabang kekuasaan eksekutif atau yudikatif, dinamakan pengaduan konstitusional (constitutional complaint). Dalam praktik, perbedaan antara pengujian konstitusionalitas norma hukum (judicial review) dan pengujian konstitusionalitas perbuatan atau kelalaian (constitutional complaint) bukanlah perbedaaan yang bersifat fundamental, sebab ia bertolak dari landasan teori yang sama, yaitu teori tentang tugas pengujian konstitusional untuk melindungi setiap warga negara dari penyalahgunaan kekuasaan oleh lembaga negara. ${ }^{46}$

Upaya constitusional complaint terhadap keputusan tata usaha negara atau beschikking bukan berarti mengesampingkan pengadilan tata usaha negara. Keputusan tata usaha negara dapat digugat jika terdapat salah satu alasan berikut ${ }^{47}$ :

a) bertentangan dengan peraturan perundang-undangan, dimana pengertian "bertentangan dengan perundang-undangan yang berlaku" terdiri dari bertentangan dengan ketentuan dalam peraturan perundang-undangan yang bersifat prosedural/formal, bertentangan dengan ketentuan dalam peraturan perundangundangan yang bersifat materil/substansial, atau dikeluarkan oleh badan atau pejabat yang tidak berwenang;

\footnotetext{
44 Jimly Asshiddiqie, Model-Model Pengujian Konstitusional Berbagai Negara, Sinar Grafika, Jakarta, 2010, hlm 30

45 Najichah, Constitutional Complaint Perspektif Politik Hukum (Menyoal Keadilan Hukum dan Hak Konstitusi di Indonesia), Vol. 2 No. 2, Jurnal Agama dan Hak Asasi Manusia In Right, Mei 2012, hlm 297

46 Supra no. 10, hlm 275

47 Id., hlm. 155-156
} 
b) badan atau pejabat tata usaha negara pada waktu mengeluarkan keputusan telah menggunakan wewenangnya untuk tujuan lain dari maksud diberikannya wewenang tersebut;

c) badan atau pejabat tata usaha negara pada waktu mengeluarkan atau tidak mengeluarkan keputusan, setelah mempertimbangkan semua kepentingan, seharusnya tidak sampai pada pengambilan atau tidak pengambilan keputusan tersebut.

Dalam hal suatu keputusan tata usaha negara bertentangan dengan ketentuan dalam peraturan perundang-undangan, berarti terdapat kemungkinan bahwa suatu keputusan tata usaha negara digugat karena melanggar hak konstitusionalitas yang diatur dalam UUD 1945. Artinya, keputusan tata usaha negara digugat dengan dalil bahwa keputusan tersebut bertentangan dengan substansi dalam UUD 1945 yang mengatur tentang hak konstitusional. Dalam konteks ini, terdapat upaya hukum untuk menggugat keputusan tersebut ke pengadilan tata usaha negara, namun apabila nantinya putusan pengadilan tata usaha negara tersebut dianggap belum dapat memberikan rasa keadilan, seharusnya di sinilah peran constitutional complaint yaitu menilai keputusan tata usaha negara tersebut yang dianggap bertentangan dengan hak-hak asasi warga negara yang diatur dalam UUD 1945. Secara konkret, gugatan individu yang hak konstitutionalnya dirugikan oleh keputusan tata usaha negara hanya dapat diajukan constitutional complaint ke Mahkamah Konstitusi apabila upaya hukum melalui pengadilan tata usaha negara telah ditempuh dan tidak lagi tersedia upaya hukum lain.

Hal ini juga berlaku terhadap putusan pengadilan (vonis) mengenai suatu kasus tertentu, untuk menilai apakah putusan dari Mahkamah Agung melanggar hak-hak konstitusi warga negara terutama terkait putusan Mahkamah Agung yang bersifat final. Contohnya putusan kasasi yang telah memiliki kekuatan hukum tetap tetapi merugikan hak konstitusional seseorang. Meski demikian produk hukum yang berasal dari ranah Mahkamah Agung harus tetap didahului dengan upaya-upaya hukum yang telah disediakan oleh aturan perundang-undangan. Secara umum, kasus yang akan diajukan ke Mahkamah Konstitusi untuk bisa diselesaikan melalui constitutional complaint, pengadu (complainant) sebelumnya 
telah melakukan semua upaya hukum yang tersedia ke lembaga berwenang mengenai tindakan yang dianggap inkonstitusional yang dideritanya. Hal yang perlu diperhatikan adalah dalam constitutional complaint, Mahkamah Konstitusi tidak boleh menjadi pengadilan perkara. Mahkamah Konstitusi hanya menguji konstitusionalitas berdasarkan UUD $1945 .{ }^{48}$ Jika ada putusan pengadilan yang dianggap bertentangan dengan hak konstitusional warga negara dan diajukan sebagai constitutional complaint dan Mahkamah Konstitusi mengabulkan perkaranya maka Mahkamah Konstitusi tidak akan mengambil alih perkaranya, tapi perkara akan dikembalikan ke pengadilan untuk diperiksa kembali dengan cara yang tidak bertentangan dengan konstitusi. Sehingga kewenangan lembaga manapun tidak akan ada yang diambil alih oleh Mahkamah Konstitusi.

Perbuatan atau kelalaian pejabat publik, baik dari cabang kekuasaan eksekutif ataupun yudikatif yang mengakibatkan terlanggar atau tidaknya hak-hak konstitusional warga negara juga jelas dapat menjadi objek dalam pengaduan konstitusional. Salah satu contoh yang terjadi adalah ketika seorang pejabat tidak melaksanakan putusan dari PTUN yang memutuskan pejabat yang bersangkutan untuk memenuhi hak-hak konstitusional dari penggugat. Hal demikian hanyalah salah satu contoh dari sekian banyak perbuatan atau kelalaian pejabat publik yang dapat melanggar hak konstitusional warga negara. Dalam hal ini pengaduan konstitusional dapat menjadi upaya hukum yang dapat ditempuh oleh warga negara untuk dapat memenuhi hak konstitusionalnya.

\section{Hambatan Pelaksanaan Constitutional Complaint dari Sisi Sosial dan Politik di Indonesia}

Wacana pelaksanaan constitutional complaint di Indonesia tidak terlepas dari hambatan-hambatan yang dapat terjadi apabila Indonesia memiliki lingkup kuasa kehakiman untuk menangani perkara constitutional complaint. Hambatan tersebut dapat dilihat dari sisi sosial masyarakat Indonesia yang majemuk maupun dari sisi budaya politik yang ada. Hambatan tersebut perlu untuk

48 Supra no. 46, hlm 297-298 
dipertimbangkan agar dalam praktiknya pelaksanaan constitutional complaint dapat bekerja dengan efektif dan sesuai dengan hakikat awal dari konsep constitutional complaint itu sendiri.

Apabila dilihat dari sisi sosial masyarakat Indonesia, adanya suatu kekhawatiran terjadinya ledakan jumlah pengaduan sangat mungkin terjadi jika penafsiran pelanggaran hak konstitusional belum konkrit. Banyaknya pengaduan dengan menggunakan constitutional complaint tidak dapat dihindari terlepas dari sesuai atau tidaknya kasus tersebut dimasukkan ke dalam kategori mekanisme constitutional complaint. Hal tersebut berkaitan dengan pemahaman konsep hukum atas constitutional complaint baik secara konseptual maupun mekanisme yang belum merata di kalangan masyarakat Indonesia yang bersifat majemuk dan heterogen. Dalam hal ini tergantung pada perubahan dan perkembangan yang terjadi di tengah masyarakat. Banyaknya constitutional complaint dapat dihindari seiring dengan kedewasaan masyarakat dalam memahami konstitusi yang tidak hanya dalam tataran konseptual saja tetapi sudah menjangkau ke arah mekanisme.

Apabila dilihat dari sisi politik, salah satu hambatan praktik constitutional complaint akan berkaitan dengan eksekusi dari putusan constitutional complaint. Hal ini dapat diperbandingkan dengan praktik sejumlah negara yang budaya politiknya sudah maju seperti Jerman dan Amerika. Menurut pendapat Palguna terkait dengan eksekusi putusan constitutional complaint, dalam praktiknya negara-negara tersebut memutuskannya hanya secara deklaratif, namun jika ada pejabat yang tidak melaksanakan putusan Mahkamah Konstitusi tersebut maka di hadapan publik langsung "nol nilainya"49. Berbeda dengan Indonesia yang kesadaran budaya politik dan etikanya belum terbangun dengan baik. Apabila putusan constitutional complaint tidak dilaksanakan, apakah masyarakat Indonesia yang tingkat pendidikan dan budaya politiknya masih rendah mampu memberikan penilaian yang sesuai, bahkan lebih jauh menjadi eksekutor bagi

\footnotetext{
${ }^{49}$ Gresnews.com, "Menimbang Constitutional Complaint di Tangan MK", http://www.mahkamahkonstitusi.go.id/index.php?page=web.Berita\&id=11641\#.WXhO7zcxXIU, diakses tanggal 26 Juli 2017
} 
pejabat yang bersangkutan. Sebab tidak mungkin dibentuk lembaga baru untuk mengeksekusi putusan constitutional complaint. Dalam hal ini eksekusi putusan constitutional complaint sangat tergantung pada komitmen penyelenggara negara bersangkutan dan masyarakat (publik) yang menjadi penilai bahkan eksekutor bagi pejabat yang tidak melaksanakan putusan Mahkamah Konstitusi.

Pendapat lain yang dikemukakan oleh Arsil menyatakan bahwa kewenangan constitutional complaint justru sebenarnya seakan sudah menjadi kewenangan dari Mahkamah Agung dan sering terjadi kesalahan dalam praktik. Arsil memberi contoh dalam KUHAP Pasal 253 ayat (2) soal syarat kasasi disebutkan apabila terdapat cara mengadili yang tidak tepat maka Mahkamah Agung memerintahkan pengadilan yang memutus atau pengadilan lainnya yang setingkat untuk memeriksa ulang sebagian atau seluruh perkara. Namun dalam praktiknya Mahkamah Agung justru memeriksa dan memutus perkara itu sendiri dan tidak memerintahkan pengadilan sebelumnya yang memutus perkara tersebut atau pengadilan lainnya untuk memeriksa ulang perkara. Apabila Mahkamah Konstitusi diberikan kewenangan constitutional complaint dikhawatirkan dalam praktiknya Mahkamah Konstitusi juga akan menjadi pengadilan yang memeriksa dan memutus perkara tersebut sendiri, sama seperti yang terjadi dalam praktik di Mahkamah Agung. ${ }^{50}$

\section{Penutup}

Apabila melihat dari perbandingan negara Jerman dan Korea dimana pengaduan konstitusional menjadi mekanisme penting dalam melindungi hak-hak konstitusional warga negara dan pandangan pro dan kontra dari beberapa pakar hukum tata negara Indonesia mengenai urgensi pemberian kewenangan penanganan constitutional complaint kepada Mahkamah Konsitusi, maka penulis mengambil kesimpulan bahwa kewenangan menangani perkara constitutional complaint oleh Mahkamah Konstitusi merupakan kewenangan yang penting untuk diterapkan di Indonesia. Penambahan wewenang constitutional complaint pada

50 Id. 
Mahkamah Konstitusi akan lebih efektif melalui judicial interpretation oleh Mahkamah Konstitusi tanpa harus menunggu amandemen UUD 1945 atau perubahan atas UU Mahkamah Konstitusi. Constitutional complaint dapat diberlakukan terhadap semua jenis keputusan yang dikeluarkan yang patut diduga melanggar hak konstitusi, yaitu produk legislatif atau regeling, produk eksekutif (berupa keputusan atau beschikking), dan produk yudikatif (berupa putusan atau vonis). Perbuatan atau kelalaian pejabat publik, baik dari cabang kekuasaan eksekutif ataupun yudikatif yang mengakibatkan terlanggar atau tidaknya hak-hak konstitusional warga negara juga jelas dapat menjadi objek dalam pengaduan konstitusional. Dalam constitutional complaint, Mahkamah Konstitusi tidak boleh menjadi pengadilan perkara dan hanya menguji konstitusionalitas berdasarkan UUD 1945. Hambatan yang mungkin dapat terjadi dalam penerapan constitutional complaint baik dari sisi sosial maupun politik juga harus dipertimbangkan agar pelaksanaan constitutional complaint dapat berjalan dengan efektif dan sesuai dengan hakikat awal dari konsep constitutional complaint itu sendiri.

\section{Daftar Pustaka}

\section{Buku:}

I Dewa Gede Palguna, Pengaduan Konstitusional Upaya Hukum terhadap Pelanggaran Hak- Hak Konstitusional Warga Negara, Sinar Grafika, Jakarta, 2013

Jimly Asshiddiqie, Menuju Negara Hukum yang Demokratis, Sekretariat Jenderal dan Kepaniteraan Mahkamah Konstitusi, Jakarta, 2008

Jimly Asshiddiqie, Model-Model Pengujian Konstitusional Berbagai Negara, Sinar Grafika, Jakarta, 2010

Mahfud M.D, Demokrasi dan Konstitusi di Indonesia, Rineka Cipta, Jakarta, 2003

Mahfud M.D, Konstitusi dan Hukum Dalam Kontroversi Isu, Rajawali Press, Jakarta, 2009

Maria Farida, Ilmu Perundang-Undangan I: Jenis, Fungsi dan Materi Muatan, Kanisius, Yogyakarta, 2007

\section{Jurnal:}

Achmad Edi Subiyanto, Perlindungan Hak Konstitusional Melalui Pengaduan Konstitusional, Vol 8, No. 5, Jurnal Konstitusi, , Oktober 2011 
Hamdan Zoelva, Constitutional Complaint dan Constitutional Question dan Perlindungan Hak-hak Konstitusional Warga Negara, Vol.19, No.1, Jurnal Media Hukum, Juni 2012

Najichah, Constitutional Complaint Perspektif Politik Hukum (Menyoal Keadilan Hukum dan Hak Konstitusi di Indonesia), Vol. 2, No. 2, Jurnal Agama dan Hak Asasi Manusia In Right, Mei 2012

Rahmat Muhajir Nugroho, Urgensi Pengaturan Perkara Constitutional Complaint dalam Kewenangan Mahkamah Konstitusi, Vol.7, No.1, Jurnal Ilmu Hukum Novelty, Februari 2016

Solidaman Bertho Plaituka, Constitutional Complaint Dalam Rangka Penegakan Hak Asasi Manusia di Republik Indonesia, Vol. 23, No.1, Jurnal Media Hukum, Juni 2016

Vino Devanta Krisdanar, Menggagas Constitutional Complaint dalam Memproteksi Hak Konstitusional Masyarakat Mengenai Kehidupan dan Kebebasan Beragama di Indonesia, Vol. 7, No.3, Jurnal Konstitusi, 2010

Zaka Firma Aditya, Kewenangan Mahkamah Konstitusi Dalam Menyelesaikan Perkara Constitutional Complaint Berdasarkan Undang-Undang Dasar Tahun 1945, Vol. 3, No. 1, Unnes Law Journal, 2014

\section{Peraturan Perundang-Undangan:}

Undang-Undang Dasar Negara Republik Indonesia Tahun 1945

Undang-Undang Nomor 24 Tahun 2003 tentang Mahkamah Konstitusi (Lembaran Negara Republik Indonesia Tahun 2003 Nomor 98, Tambahan Lembaran Negara Republik Indonesia Nomor 4316) sebagaimana diubah terakhir dengan Peraturan Pemerintah Pengganti Undang-Undang Nomor 1 Tahun 2013 tentang Perubahan Kedua Atas Undang-Undang Nomor 24 Tahun 2003 tentang Mahkamah Konstitusi (Lembaran Negara Republik Indonesia Tahun 2013 Nomor 167, Tambahan Lembaran Negara Republik Indonesia Nomor 5456) jo Undang-Undang Republik Indonesia Nomor 4 Tahun 2014 Tentang Penetapan Peraturan Pemerintah Pengganti Undang-Undang Nomor 1 Tahun 2013 Tentang Perubahan Kedua Atas Undang- Undang Nomor 24 Tahun 2003 Tentang Mahkamah Konstitusi Menjadi Undang-Undang (Lembaran Negara Republik Indonesia Tahun 2014 Nomor 5, Tambahan Lembaran Negara Republik Indonesia Nomor 5493)

\section{Internet:}

Gresnews.com, "Menimbang Constitutional Complaint di Tangan MK", http://www.mahkamahkonstitusi.go.id/index.php?page=web.Berita\&id=1164 1\#.WXh07zcxXIU, diakses tanggal 26 Juli 2017

Siahaan, Maruarar, "Hak Konstitusional Dalam UUD 1945", ama.elsam.or.id/downloads/1322798965_Hak_Konstitusional_Dalam_UUD_19 45, diakses tanggal 27 Juli 2017 